\title{
Evidence that lamprey GnRH-III does not release FSH selectively in cattle
}

\author{
M Amstalden ${ }^{1,2,3}$, D A Zieba ${ }^{1,2,3}$, M R Garcia ${ }^{1,2,3}$, R L Stanko ${ }^{1,4}$, T H Welsh Jr ${ }^{2}$, W H Hansel ${ }^{5}$ \\ and G L Williams ${ }^{1,2,3}$ \\ ${ }^{1}$ Animal Reproduction Laboratory, Texas A\&M University Agricultural Research Station, Beeville, Texas 78102, \\ USA, ${ }^{2}$ Department of Animal Science and ${ }^{3}$ Center for Animal Biotechnology and Genomics, Texas A\&M \\ University, College Station, Texas 77843, USA, ${ }^{4}$ Department of Animal and Wildlife Sciences, Texas A\&M \\ University-Kingsville, Kingsville, Texas 78363 USA and ${ }^{5}$ Pennington Biomedical Research Center, Louisiana State \\ University, Baton Rouge, Louisiana 70808, USA
}

Correspondence should be addressed to G L Williams; Email: glw@fnbnet.net

\begin{abstract}
Experiments were performed to test the hypothesis that lamprey GnRH-III (IGnRH-III) selectively releases FSH. Primary cultures of bovine adenohypophyseal cells were treated with mammalian $\mathrm{GnRH}(\mathrm{mGnRH})$ and IGnRH-III $\left(\mathbf{1 0}^{-9}, \mathbf{1 0}^{-8}, \mathbf{1 0}^{-7}\right.$ and $10^{-6} \mathrm{M}$ ) or control media in Experiment 1. All doses of $\mathrm{mGnRH}$ and the two highest doses of IGnRH-III stimulated $(P<0.001)$ a non-selective release of $\mathrm{LH}$ and FSH. In Experiments $2-4$, Latin Square designs were utilized in vivo to examine whether physiological and hormonal milieu regulate putative selective effects of IGnRH-III. In Experiments 2 and 3 , ovariectomized cows with basal levels of estradiol only (Experiment 2) or in combination with luteal phase levels of progesterone (Experiment 3) were injected with $\mathrm{mGnRH}$ and IGnRH-III $(0.055,0.11,0.165$ and $1.1 \mu \mathrm{g} / \mathrm{kg}$ body weight (BW) and saline. All doses of $\mathrm{mGnRH}$ released $(P<0.001) \mathrm{LH}$ and $\mathrm{FSH}$, but only the highest dose of IGnRH-III stimulated $(P<0.001)$ a non-selective release of both $\mathrm{LH}$ and FSH (Experiment 3). For Experiments $4 \mathrm{~A}$ and 4B, intact, mid-luteal phase cows were injected with mGnRH and IGnRH-III (1.1 $\mu \mathrm{g} / \mathrm{kg} \mathrm{BW;} \mathrm{Experiment} \mathrm{4A),} \mathrm{IGnRH-III} \mathrm{(1.1} \mathrm{and} 4.4 \mu \mathrm{g} / \mathrm{kg} \mathrm{BW;} \mathrm{Experiment} \mathrm{4B)} \mathrm{and}$ saline. As before, $\mathrm{mGnRH}$ released $(P<\mathbf{0 . 0 0 1})$ both $\mathrm{LH}$ and FSH at all doses. In contrast, IGnRH-III at the highest dose released $(P<0.001)$ LH but not FSH. These findings suggest that IGnRH-III may act as a weak competitor for the $\mathrm{mGnRH}$ receptor and do not support the hypothesis that it selectively releases $\mathrm{FSH}$ in cattle.

Reproduction (2004) 127 35-43
\end{abstract}

\section{Introduction}

Synthesis and secretion of the gonadotropins, luteinizing hormone $(\mathrm{LH})$ and follicle-stimulating hormone $(\mathrm{FSH})$, are regulated by the hypothalamic peptide, gonadotropinreleasing hormone (GnRH) (Knobil 1980). However, secretion of FSH is less dependent upon $\mathrm{GnRH}$ control and is instead regulated largely by $\mathrm{GnRH}$-independent factors that include gonadal activins, inhibins and follistatins (Clarke et al. 1983, Pau et al. 1991, Kovacs et al. 1993).

In addition to the roles of $\mathrm{GnRH}$ and gonadal hormones in controlling the secretion of FSH, the existence of a separate, highly specific FSH-releasing hormone (FSH-RH) of hypothalamic origin has been proposed. Experimental evidence to support this theory has included the identification of separate fractions of $\mathrm{FSH}-\mathrm{RH}$ and $\mathrm{LH}$-releasing hormone activity in sheep hypothalamic extracts (Dhariwal et al. 1965), as well as selectively impaired release of FSH after lesioning of the dorsal anterior hypothalamic area (Lumpkin \& McCann 1984) and posterior/mid infundibulum (Marubayashi et al. 1999). Moreover, $\mathrm{GnRH}$-independent pulses of FSH have been detected by determining concentrations of FSH in the hypothalamichypophyseal portal circulation (Padmanabhan et al. 2003).

Biochemically, several alternative forms of GnRH have been identified in vertebrates (Dubois et al. 2002) and have been examined as candidates for selective FSH-RH activity. One of these, identical to chicken GnRH-II, and its receptor have been identified in mammals (Lescheid et al. 1997, Millar et al. 2001). Although not isolated in mammals to date, an alternative form of GnRH, lamprey GnRH-III (IGnRH-III) (Sower et al. 1993), has been 
reported to selectively stimulate the release of $\mathrm{FSH}$ in rodents (Yu et al. 1997) and in cattle during the luteal phase of the estrous cycle (Dees et al. 2001). However, several other studies, both in vitro (Yu et al. 1997, Lovas et al. 1998, Montaner et al. 2001, Kovacs et al. 2002) and in vivo (Kovacs et al. 2002), have questioned the ability of IGnRH-III to selectively release FSH in rodents. Clearly, the existence of a distinct mammalian FSH-RH could have far-reaching implications in both medicine and agriculture. Therefore, the objectives of studies reported herein were to assess the ability of IGnRH-III to preferentially release $\mathrm{FSH}$ in an array of physiological contexts in cattle.

\section{Materials and Methods}

All experimental procedures involving animals in these studies were approved by the Institutional Agricultural Animal Care and Use Committee of The Texas A\&M University System.

\section{Synthesis of IGnRH-III}

IGnRH-III was synthesized by the Protein Facility at Louisiana State University. The peptide was found to be $100 \%$ pure by HPLC and exhibited a mass spectrophotometric peak of 1259.5 (molecular mass of IGnRH-III is $1259 \mathrm{Da})$.

\section{Experiment 1: effects of IGnRH-III in primary adenohypophyseal cell cultures}

Hypophyses were collected from steers at slaughter at the Rosenthal Meat Science Center, Texas A\&M University, College Station, Texas and kept on ice until tissue processing. Adenohypophyses were dissected from the neurohypophysis and adenohypophyseal cells were dispersed enzymatically as described previously (Welsh et al. 1986, Tanner et al. 1990). Dispersed cells from two steers were combined, plated in six-well plates, and cultured in Dulbecco's modified Eagle's medium (DMEM) containing $10 \%$ fetal calf serum for 4 days. On day 4 , cells were incubated with serum-free DMEM overnight. On the next day, cells were treated with DMEM alone (control), DMEM containing $10^{-6}, 10^{-7}, 10^{-8}$ or $10^{-9} \mathrm{M}$ mammalian GnRH-I (mGnRH) (Bachem Inc., Torrance, CA, USA) or DMEM containing IGnRH-III at the same concentrations as $\mathrm{mGnRH}$ for $4 \mathrm{~h}$. Each treatment was applied to six wells. At the end of the $4 \mathrm{~h}$ incubation, culture media were harvested, and stored at $-20^{\circ} \mathrm{C}$ until assayed for $\mathrm{LH}$ and $\mathrm{FSH}$. Three independent replications were performed.

\section{Experiment 2: effects of IGnRH-III in ovariectomized cows with basal circulating concentrations of estradiol}

Seven ovariectomized cows, each bearing a Silastic (Dow Corning Corporation, Midland, MI, USA) ear implant containing crystalline estradiol 17- $\beta$ (Sigma, St Louis, MO, USA), were used. This animal model has been used extensively to study the neuroendocrine control of gonadotropin secretion in cattle without the complications associated with ovarian cyclicity. In this experiment, implants provided mean concentrations ( \pm s.E.M.) of estradiol of $5.46 \pm 0.16 \mathrm{pg} / \mathrm{ml}$. Cows were injected i.v. with (i) physiological saline (control), (ii) $\mathrm{mGnRH}$ in saline $(0.055,0.11$ and $0.165 \mu \mathrm{g} / \mathrm{kg}$ body weight (BW), and (iii) IGnRH-III (same doses as mGnRH) in a Latin Square design, such that each cow received one of the treatments in random order on each day of a 7 day experiment. Therefore, each treatment was applied only once to each experimental cow and no more than one treatment was applied to each cow on a given day. Blood was collected by venipuncture immediately prior to treatment (time 0) and at 10, 30, 60, 120 and $240 \mathrm{~min}$ after injections.

\section{Experiment 3: effects of IGnRH-III in the presence of basal estradiol and mid-luteal phase levels of progesterone}

Five ovariectomized cows, each bearing estradiol implants similar to those described in Experiment 2, were used. Cows had mean ( \pm S.E.M.) concentrations of estradiol of $4.88 \pm 0.19 \mathrm{pg} / \mathrm{ml}$. To mimic luteal-phase concentrations of progesterone, cows received a single controlled release drug delivery device (CIDR) (Pharmacia Animal Health, Kalamazoo, MI, USA) intravaginally 2 days before the experiment began. CIDR devices were left in place for the duration of the experiment. In addition, i.m. injections of $100 \mathrm{mg}$ progesterone (Sigma) diluted in vegetable oil were administered daily. Injections of progesterone started on the day before the experiment began and continued for the duration of the study, producing mean ( \pm S.E.M.) concentrations of progesterone of $8.8 \pm 0.5 \mathrm{ng} / \mathrm{ml}$. Cows were treated i.v. with (i) saline (control), (ii) $\mathrm{mGnRH}$ in saline (0.11 or $1.1 \mu \mathrm{g} / \mathrm{kg} \mathrm{BW),} \mathrm{and} \mathrm{(iii)} \mathrm{IGnRH-III} \mathrm{in} \mathrm{saline} \mathrm{(same}$ doses as for $\mathrm{mGnRH}$ ) in a Latin Square design (i.e. each cow received one treatment in random order on each day of the 5 day experiment as in Experiment 2). Therefore, each treatment was applied only once to each experimental cow and no more than one treatment was applied to each cow on a given day. Blood was collected by venipuncture immediately prior to treatment (time 0 ) and at 10, 30, 60, 120 and 240 min after injections.

\section{Experiment 4: effects of IGnRH-III during the mid-luteal phase of the estrous cycle}

\section{Experiment $4 \mathrm{~A}$}

Estrous cycles were synchronized in six cows using a 7 day treatment with CIDR devices and an injection of a synthetic prostaglandin analog, dinoprost tromethamine (Lutalyse; Pharmacia Animal Health, Kalamazoo, MI, USA) on the day of CIDR removal. On day 10, 11 or 12 
after estrus, cows were injected i.v. with (i) saline (control), (ii) $\mathrm{mGnRH}$ in saline $(1.1 \mu \mathrm{g} / \mathrm{kg} \mathrm{BW}$ ), and (iii) IGnRH-III $(1.1 \mu \mathrm{g} / \mathrm{kg}$ BW) in two replicates with three cows per replicate. As in Experiments 2 and 3, releasing hormone treatments or saline were administered in a Latin Square design in a 3 day experiment and no more than one treatment was applied to each cow on a given day. Blood was collected by venipuncture immediately prior to treatment (time 0) and at 10, 30, 60, 120 and $240 \mathrm{~min}$ after injections. Mean concentrations ( \pm S.E.M.) of progesterone observed during this experiment were $4.2 \pm 0.25 \mathrm{ng} / \mathrm{ml}$.

\section{Experiment $4 B$}

Because of an apparent change in sensitivity to IGnRH-III in mid-luteal phase cows in Experiment 4A (see Results) compared with ovariectomized cows (Experiments 2 and 3 ), higher doses of IGnRH-III were tested in this experiment. Three intact cows with estrous cycles synchronized using a single injection of Lutalyse administered during the mid-luteal phase were used. Cows were injected i.v. with (i) saline (control) or (ii) $\mathrm{IGnRH}-\mathrm{III}$ in saline $(1.1$ or $4.4 \mu \mathrm{g} / \mathrm{kg}$ BW). Injections were administered in a Latin Square design in a 3 day experiment and no more than one treatment was applied to each cow on a given day, as in previous experiments. Because synchronization of estrus using only a prostaglandin can result in a wide distribution in time of onset of estrus compared with other methods, the stage of follicular development at the time of corpus luteum regression (Bó et al. 2002) could potentially influence the regulation of $\mathrm{FSH}$. To minimize these effects, two cows were used on days $10-12$ and one cow was used on days 11-13 after estrus. Blood was collected by venipuncture immediately prior to treatment (time 0) and at 10, 30, 60, 120 and $240 \mathrm{~min}$ after injections. Mean concentrations ( \pm S.E.M.) of progesterone observed during the experiment were $4.5 \pm 0.41 \mathrm{ng} / \mathrm{ml}$.

\section{RIAs}

Concentrations of $\mathrm{LH}$ in culture media collected from each well (Experiment 1) and in serum (Experiments 2-4) were determined with a validated RIA as described previously (McVey \& Williams 1991). Intra- and interassay coefficients of variation averaged 5.9 and $10.6 \%$ respectively. Concentrations of FSH in culture media (Experiment 1) and serum (Experiments 2-4) were determined using an RIA described previously by Krystek et al. (1985). In this assay, a highly purified ovine FSH (oFSH) (AFP 5679C; National Hormone and Pituitary Program (NHPP), Harbor-UCLA Medical Center, Torrance, CA, USA) was used as both the reference preparation and as iodinated tracer. Antiserum produced in rabbits immunized against oFSH was utilized as the primary antiserum. This antiserum shows similar cross-reactivity between partially purified preparations of oFSH (oFSH S8 and S9; NHPP) and bovine FSH (bFSH B1; NHPP) and does not cross-react with other pituitary hormones (Krystek et al. 1985). Sensitivity of the assay averaged $0.05 \mathrm{ng} / \mathrm{ml}$. Intra- and interassay coefficients of variation averaged 5.7 and $9.6 \%$ respectively.

Because of the heterogeneity of FSH molecules (Padmanabhan et al. 1992) and varied sources of reference hormones, iodinated tracers and antiserum in RIAs for ruminant $\mathrm{FSH}$, the above RIA plus two additional FSH assay systems were compared in Experiment 3. Assay 2, referred to hereafter as the Bolt assay, used a bFSH preparation (AFP 5332B; NHPP) as both the reference preparation and as iodinated tracer (Bolt \& Rollins 1983). The antiserum (US Department of Agriculture (USDA) $5-0122)$ utilized in this assay was raised against bFSH- $\beta$ and reacts with intact molecules of $\mathrm{FSH}$, but does not react significantly with the $\alpha$-subunit of bFSH or other pituitary hormones (Bolt \& Rollins 1983). Sensitivity of the single assay performed was $0.05 \mathrm{ng} / \mathrm{ml}$. The intra-assay coefficient of variation averaged $7.2 \%$. The third RIA system utilized highly purified bFSH (AFP-5332B; NHPP) as the reference preparation and iodinated tracer. The antiserum (AFP7711690; NHPP) was raised against intact $\mathrm{bFSH}$. Sensitivity of the single assay performed was $0.06 \mathrm{ng} / \mathrm{ml}$. The intra-assay coefficient of variation averaged $5.6 \%$.

Serum concentrations of estradiol were determined in extracted samples in a single assay as reported previously (Talavera et al. 1985). Concentrations of progesterone were determined in selected samples in a single assay with the Coat-A-Count direct assay (Diagnostic Products, Los Angeles, CA, USA) as reported previously from this laboratory (Fajersson et al. 1999). Sensitivity for estradiol and progesterone assays was $3.7 \mathrm{pg} / \mathrm{ml}$ and $0.05 \mathrm{ng} / \mathrm{ml}$ respectively. The intra-assay coefficients of variation for these assays averaged 2.7 and $4.2 \%$ respectively.

\section{Statistical analysis}

In Experiment 1, $\mathrm{LH}$ and $\mathrm{FSH}$ data were analyzed by ANOVA using the general linear models procedure (PROC GLM) of the Statistical Analysis System (SAS 8.1; SAS Institute Inc., Cary, NC, USA). Sources of variation were treatment, well(treatment), replication, and treatment $X$ replication interaction. A significant replicate effect was observed; thus, treatment effects were analyzed for each replication. The least significant difference was used to compare means when significant differences were detected by ANOVA.

In Experiments 2-4, $\mathrm{LH}$ and $\mathrm{FSH}$ data were analyzed by ANOVA using the PROC GLM procedure of SAS for a Latin Squares design. Sources of variation were cow, day and treatment. The least squares means procedure was used to compare means when significant differences were detected. Adenohypophyseal responses in each 


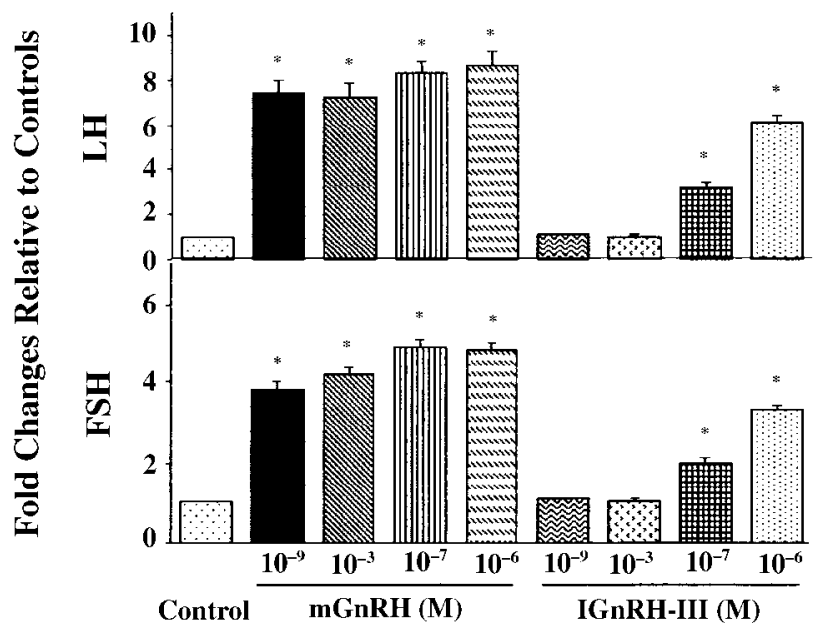

Figure 1 Fold changes in mean concentrations ( \pm S.E.M.) of LH (top) and FSH (bottom) released into the media by primary adenohypophyseal cell cultures relative to controls (Experiment 1). Data from one representative replication, which included six wells per treatment, are shown. All doses of $\mathrm{mGnRH}$ stimulated the release of $\mathrm{LH}$ and FSH into the media. The two highest doses of IGnRH-III stimulated a non-selective release of both $\mathrm{LH}$ and FSH. $* P<0.001$ compared with controls.

experiment were also analyzed by examining maximum (peak) release and areas under the response curves for $\mathrm{LH}$ and $\mathrm{FSH}$. Because results of these analyses resulted in identical interpretations to those obtained with the
ANOVA of mean concentrations following releasing hormone challenges, only the results of the latter analyses are presented in the Results.

\section{Results}

\section{Experiment 1: effects of IGnRH-III in primary adenohypophyseal cell cultures}

Differences in the magnitude of $\mathrm{LH}$ and $\mathrm{FSH}$ released into the media among replicates resulted in a significant replicate effect $(P<0.001)$. However, analysis of treatment effects within each replicate resulted in similar conclusions in all three replicates, as the interaction resulted from differences in the magnitude of change among replicates and not in direction. All doses of $\mathrm{mGnRH}$ stimulated $(P<0.001)$ the release of $\mathrm{LH}$ and $\mathrm{FSH}$. However, only the two highest doses of IGnRH-III $\left(10^{-7}\right.$ and $\left.10^{-6} \mathrm{M}\right)$ stimulated $(P<0.001)$ a non-selective release of both $\mathrm{LH}$ and $\mathrm{FSH}$. Results from one representative replication are shown in Fig. 1.

\section{Experiment 2: effects of IGnRH-III in ovariectomized cows with basal circulating concentrations of estradiol}

All doses of $\mathrm{mGnRH}(0.055,0.11$ and $0.165 \mu \mathrm{g} / \mathrm{kg})$ tested induced $(P<0.001)$ release of both $\mathrm{LH}$ and $\mathrm{FSH}$. However, none of the IGnRH-III doses tested stimulated release of either $\mathrm{LH}$ or $\mathrm{FSH}$ (Fig. 2).

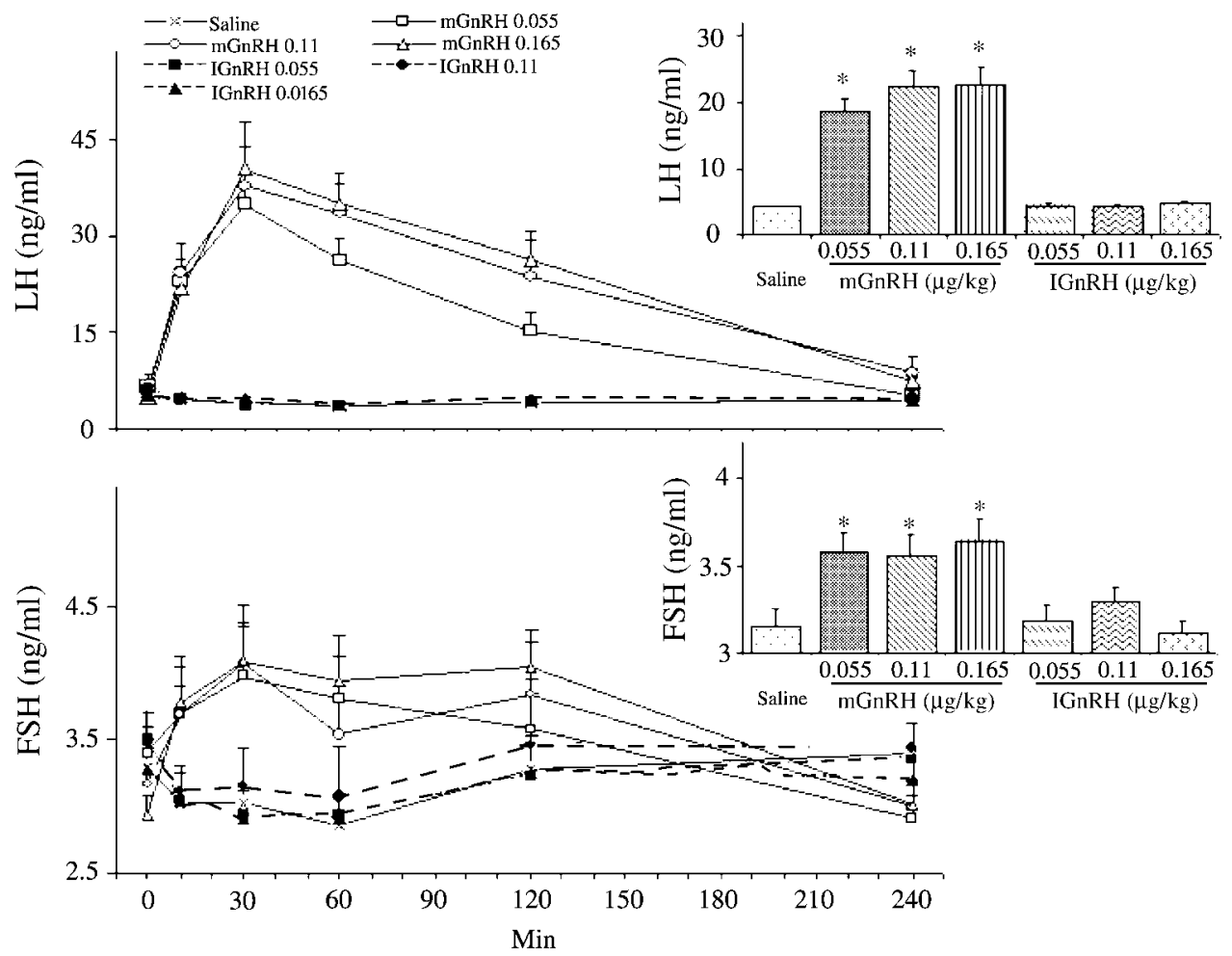

Figure 2 Temporal changes and overall mean concentrations ( \pm S.E.M.) of LH (top) and FSH (bottom) in ovariectomized cows with basal serum concentrations of estradiol and injected i.v. at time 0 with saline (control), mGnRH or IGnRH-III (Experiment 2) in a Latin Square arrangement. All doses of $\mathrm{mGnRH}$ increased overall mean concentrations of LH and FSH (insets). None of the doses of IGnRH-III stimulated the release of either gonadotropin. $* P<0.001$ compared with saline $(n=7$ cows per treatment). 


\section{Experiment 3: effects of IGnRH-III in the presence of basal estradiol and mid-luteal phase levels of progesterone}

Both doses of $\mathrm{mGnRH}(0.11$ and $1.1 \mu \mathrm{g} / \mathrm{kg})$ stimulated $(P<0.001)$ release of $\mathrm{LH}$ and $\mathrm{FSH}$ (Fig. 3). However, only the highest dose of IGnRH-III $(1.1 \mu \mathrm{g} / \mathrm{kg})$ stimulated $(P<0.001)$ a non-selective release of both $\mathrm{LH}$ and $\mathrm{FSH}$ (Fig. 3). A comparison of three FSH RIA systems, widely available for use by other investigators, produced comparable results and demonstrated that the higher dose of IGnRH-III induced $(P<0.005)$ a non-selective release of FSH (Fig. 4). No stimulation of release of FSH was observed with the lower dose.

\section{Experiment 4: effects of IGnRH-III during the mid-luteal phase of the estrous cycle}

\section{Experiment $4 \mathrm{~A}$}

In intact mid-luteal phase cows, IGnRH-III at $1.1 \mu \mathrm{g} / \mathrm{kg}$ did not stimulate $(P>0.1)$ the release of either $\mathrm{LH}$ or FSH (Fig. 5). As expected, $\mathrm{mGnRH}$ at the same dose $(1.1 \mu \mathrm{g} / \mathrm{kg})$ released $(P<0.001)$ both $\mathrm{LH}$ and FSH (Fig. 5).

\section{Experiment $4 B$}

In intact, mid-luteal phase cows, a dose of $4.4 \mu \mathrm{g} / \mathrm{kg}$ IGnRH-III stimulated $(P<0.001)$ the release of $\mathrm{LH}$, but not FSH (Fig. 6). Similar to experiment 4A, a dose of $1.1 \mu \mathrm{g} / \mathrm{kg}$ IGnRH-III did not stimulate the release of either LH or FSH (Fig. 6).

\section{Discussion}

Using both in vitro and in vivo approaches, we were unable to demonstrate that IGnRH-III can selectively stimulate the release of $\mathrm{FSH}$ in cattle. In all experimental models reported herein, when IGnRH-III induced the release of $\mathrm{FSH}$ it also induced the release of $\mathrm{LH}$. Moreover, IGnRH-III was less potent for stimulating release of either gonadotropin than $\mathrm{mGnRH}$. In the intact cow, in which the ovarian peptides inhibin and follistatin exert inhibitory control over release of FSH, IGnRH-III was even less effective for inducing release of FSH. In that model, the stimulation of $\mathrm{LH}$ secretion by $\mathrm{IGnRH}$-III during the mid-luteal phase was not accompanied by release of FSH. In contrast, $\mathrm{mGnRH}$ was always effective for inducing the
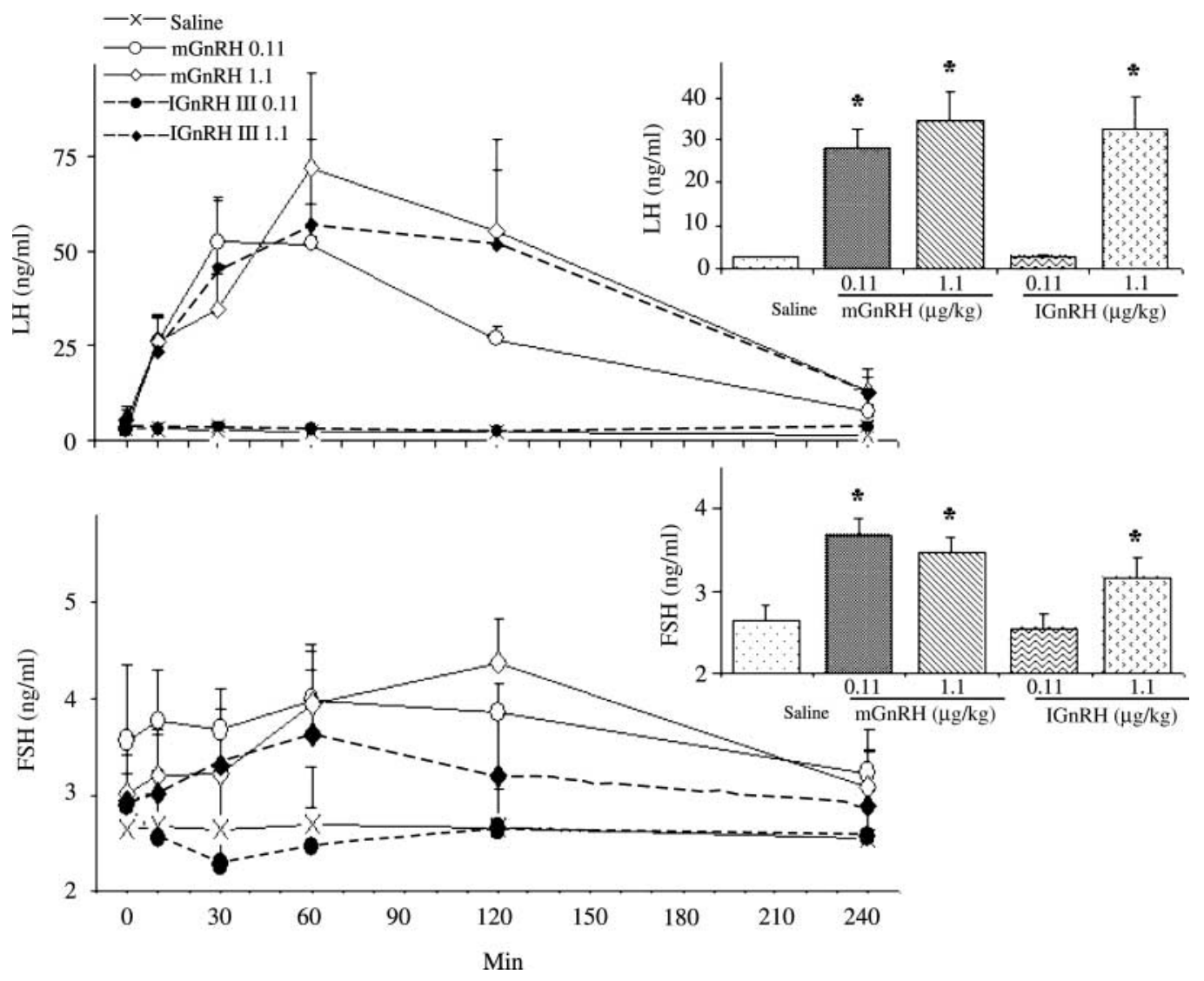

Figure 3 Temporal changes and overall mean concentrations ( \pm S.E.M.) of LH (top) and FSH (bottom) in ovariectomized cows with basal serum concentrations of estradiol and mid-luteal phase concentrations of serum progesterone (Experiment 3). Cows were injected i.v. at time 0 with saline (control), mGnRH or IGnRH-III. Both doses of mGnRH increased overall mean concentrations of LH and FSH (insets). Only the dose of $1.1 \mu \mathrm{g} / \mathrm{kg} \mathrm{IGnRH-III} \mathrm{stimulated} \mathrm{a} \mathrm{non-selective} \mathrm{release} \mathrm{of} \mathrm{both} \mathrm{gonadotropins} \mathrm{and} \mathrm{increased} \mathrm{the} \mathrm{overall} \mathrm{mean} \mathrm{concentrations} \mathrm{of} \mathrm{LH} \mathrm{and} \mathrm{FSH.}$ $* P<0.001$ compared with saline ( $n=5$ cows per treatment). 

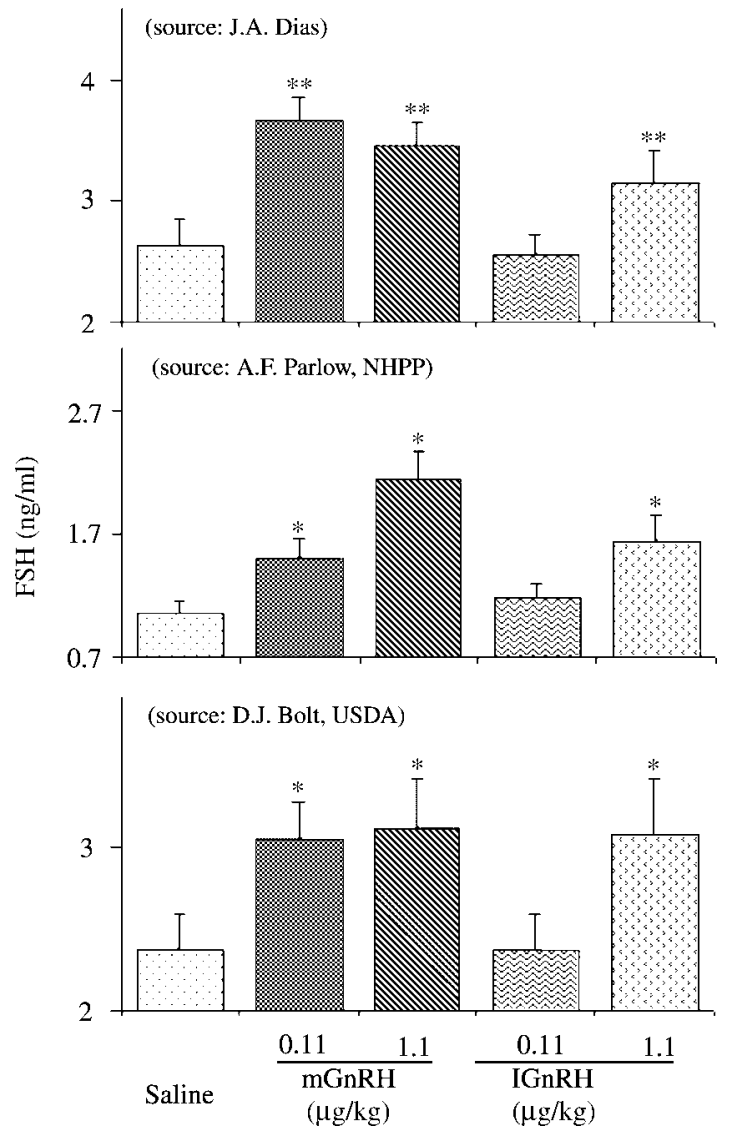

Figure 4 Comparison of three RIA systems for evaluating FSH release in Experiment 3. Both the 'Bolt' ( $\beta$-subunit) and 'Parlow' assays gave results similar to those observed with the 'Dias' assay which was used throughout all other experiments. $* P<0.005$ compared with controls, ${ }^{* *} P<0.001$ compared with controls ( $n=5$ cows per treatment).

release of both gonadotropins, independently of physiological or hormonal status. These results are in contrast to those of Dees et al. (2001), who reported selective release of FSH by low-dose IGnRH-III and failure to release $\mathrm{LH}$ during the mid-luteal phase of cattle. Our results showing no selective effect of IGnRH-III on FSH secretion are supported by recent findings in the rat (Kovacs et al. 2002).

The amino acid sequence of IGnRH-III exhibits a $60 \%$ homology to that of $\mathrm{mGnRH}$ (type I). The two molecules differ in sequence at amino acid positions 5-8, which confers distinct conformational characteristics that may account for differences in biological activity (Watts et al. 2001). Yu et al. (2000) reported selective FSH-releasing activity in fractions of gel-purified hypothalamic extracts that could be neutralized by antisera against IGnRH and proposed that the putative $\mathrm{FSH}-\mathrm{RH}$ fractions were IGnRH-III or a closely related peptide. However, Montaner et al. (2001) were unable to detect selective FSHreleasing activity in rat and hamster hypothalamic extracts purified by HPLC. At least two other reports have failed to demonstrate selective $\mathrm{FSH}$ release by $\mathrm{IGnRH}-\mathrm{III}$ in rat pituitary cells (Lovas et al. 1998, Montaner et al. 2001).
In the present study, we observed that IGnRH-III induced gonadotropin release from bovine primary adenohypophyseal cells at concentrations of $10^{-7}$ and $10^{-6} \mathrm{M}$, but not at lower concentrations. Importantly, there was no selective release of FSH by IGnRH-III, similar to that reported by Yu et al. (2002) in primary rat adenohypophyseal cells. Therefore, there is general agreement among studies that, in primary cultures of adenohypophyseal cells, IGnRH-III does not stimulate the release of gonadotropins at low concentrations, but at higher concentrations it stimulates a non-selective release of both $\mathrm{LH}$ and FSH. In contrast, in vitro studies using hemipituitaries suggested that IGnRH-III could preferentially release FSH (Yu et al. 1997, 2002). Whether the divergent effects of IGnRH-III in primary adenohypophyseal cell cultures vs hemipituitaries were due to differences in the physiological state of gonadotropes is not clear. Yu et al. (2002) proposed that the lack of selective responsiveness of cultured adenohypophyseal cells to IGnRH-III is due to the absence of gonadal steroids, resulting in a down-regulation of putative IGnRHIII receptors.

Because reports on in vivo studies testing the effects of IGnRH-III on gonadotropin secretion have been inconsistent, a careful examination of IGnRH-III action during different physiological/endocrinological states and at different doses seems prudent. Dees et al. (2001) reported that doses of 0.25 and $0.5 \mathrm{mg} \mathrm{IGnRH}$-III selectively stimulated the release of $\mathrm{FSH}$ during the luteal phase (days 9-14) of the estrous cycle in cows. However, doses of 2 or $8 \mathrm{mg} \mathrm{IGnRH}-\mathrm{III}$ released both $\mathrm{LH}$ and $\mathrm{FSH}$ during this period. In contrast, $0.5 \mathrm{mg} \mathrm{IGnRH}-\mathrm{III}$ released only $\mathrm{LH}$ during the follicular phase of the estrous cycle and was less potent in this effect than mGnRH (Dees et al. 2001). These findings are interpreted to mean that low doses of IGnRH-III have the ability to selectively stimulate $\mathrm{FSH}$ release during periods of high circulating progesterone. The report did not discuss how this occurs in the face of expected increases in circulating inhibin that are associated with the development of second-wave follicle dominance during this time period (see review by Padmanabhan et al. 2002).

In our experiments using the ovariectomized, estradiolimplanted cow without any progesterone treatment, doses of IGnRH-III of up to $0.165 \mu \mathrm{g} / \mathrm{kg}$ (equivalent to $\sim 0.075 \mathrm{mg}$ ) failed to elicit measurable release of either gonadotropin. In contrast, doses of $\mathrm{mGnRH}$ as low as $0.055 \mu \mathrm{g} / \mathrm{kg}$ (equivalent to $\sim 0.025 \mathrm{mg}$ ) effectively released both $\mathrm{LH}$ and FSH. Using the ovariectomized, estradiolimplanted cow, with exogenous progesterone treatment to simulate luteal-phase concentrations of progesterone, we observed that doses of $1.1 \mu \mathrm{g} / \mathrm{kg}$ (equivalent to $\pm 0.5 \mathrm{mg}$ ) IGnRH-III stimulated a non-selective release of both LH and FSH. Thus, similarly to the studies reported by Kovac et al. (2002) using the ovariectomized, estradiol/progesterone-treated rat, IGnRH-III did not stimulate preferential release of FSH in our studies with cattle. Moreover, during the mid-luteal phase (days 10-12) in the intact cow, doses 


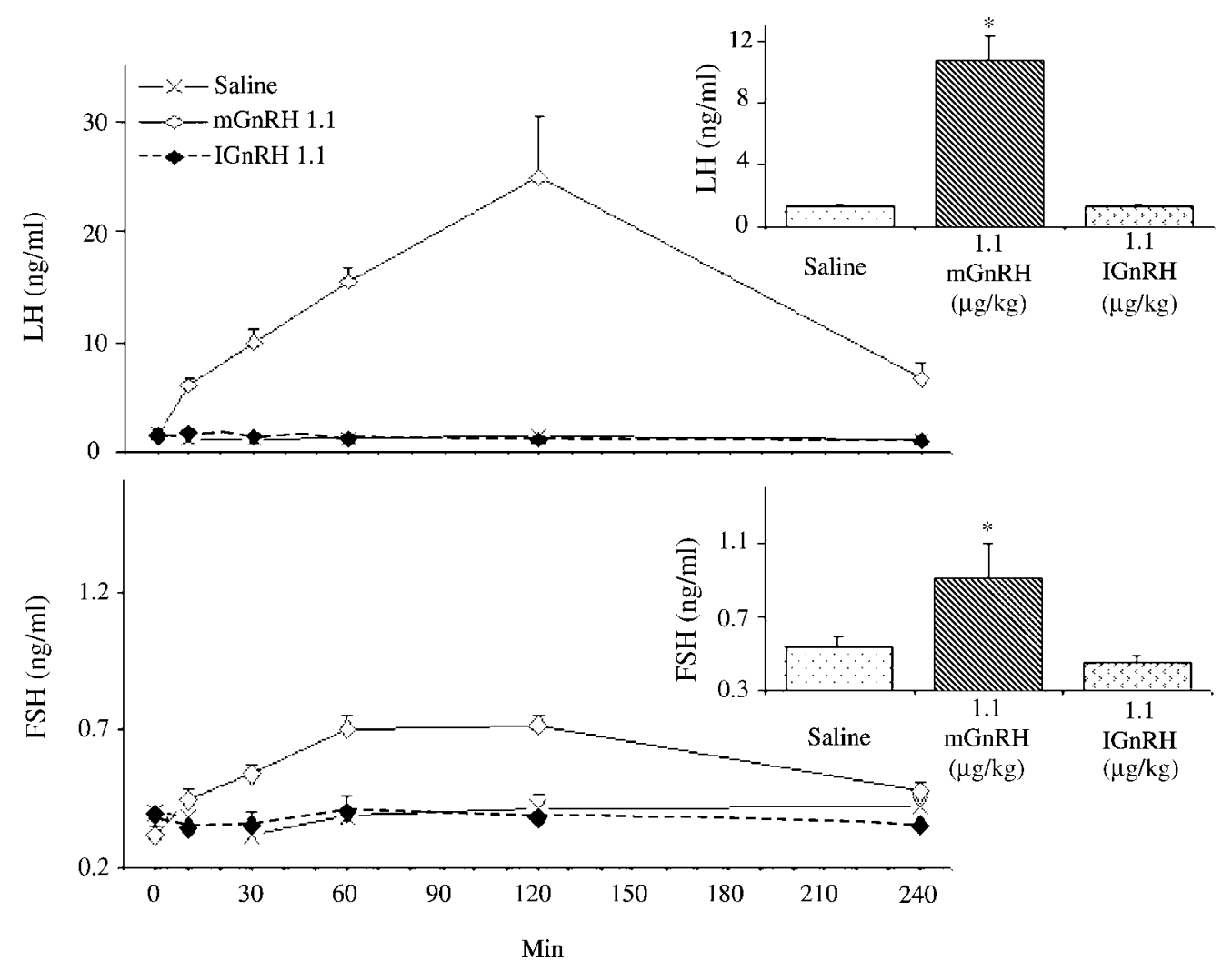

Figure 5 Temporal changes and overall mean concentrations ( \pm S.E.M.) of LH (top) and FSH (bottom) in intact cows during the mid-luteal phase of the estrous cycle (Experiment 4A). Cows were injected i.v. at time 0 with saline (control), mGnRH or IGnRH-III. Mammalian GnRH increased overall mean concentrations of $\mathrm{LH}$ and FSH (insets). IGnRH-III did not stimulate release of either gonadotropin. ${ }^{*} P<0.001$ compared with saline ( $n=6$ cows per treatment).

of $1.1 \mu \mathrm{g} / \mathrm{kg}$ IGnRH-III failed to release either $\mathrm{LH}$ or FSH. However, doses of $4.4 \mu \mathrm{g} / \mathrm{kg}$ (equivalent to $\pm 2 \mathrm{mg}$ ) IGnRH-III released only LH. Therefore, the ability of IGnRH-III to stimulate the release of gonadotropins was impaired during this period. It is generally accepted that ovarian follicular inhibins and follistatins suppress FSH secretion (Padmanabhan et al. 2002) without apparent effects on secretion of LH (Rivier et al. 1986); nonetheless, a decrease in the number of binding sites for $\mathrm{GnRH}$ induced by inhibin has been reported (Wang et al. 1988). Thus, if IGnRH-III has lower binding affinity for GnRH receptors, potential decreases in numbers of $\mathrm{GnRH}$ receptors on gonadotropes induced by ovarian hormones could also account for significantly diminished responsiveness to IGnRH-III. IGnRH-III is also less potent compared with mGnRH (type I and II) for inducing inositol-phosphate production in COS-1 cells expressing GnRH receptors I and II (Neill 2002). Therefore, while it remains possible that IGnRH-III acts on a distinct receptor other than GnRH-I or -II, as proposed by Yu et al. (2000); no sequence for GnRH receptor forms, other than types I and II and a non-functional $\mathrm{GnRH}$ receptor-like homologue, has been observed in the human genome (Neill et al. 2001).
FSH molecules are largely heterogeneous and may vary in immunological and biological activities (Padmanabhan et al. 1992). To examine whether the discordant results obtained in our experiments and those performed by Dees et al. (2001), both involving cattle, could be accounted for by potential differences in immunological assay methodology, we used three distinct RIA systems validated for use in bovine samples. All three RIAs used to determine concentrations of FSH produced similar results. Therefore, it is not likely that contrasting observations between our experiments and those performed by Dees et al. (2001) are due to differences in the ability of particular RIAs used to detect circulating FSH.

In summary, results from our experiments do not provide evidence that IGnRH-III can selectively release FSH in cattle. The identification of such a factor would have important implications in both animal agriculture and human medicine.

\section{Acknowledgements}

We acknowledge Dr A F Parlow (NHPP) for providing LH and $\mathrm{FSH}$ preparations and bovine FSH antisera, Dr Jerry Reeves (Washington State University, WA, USA) for LH antisera, Dr James Dias (New York State Department of Health, 

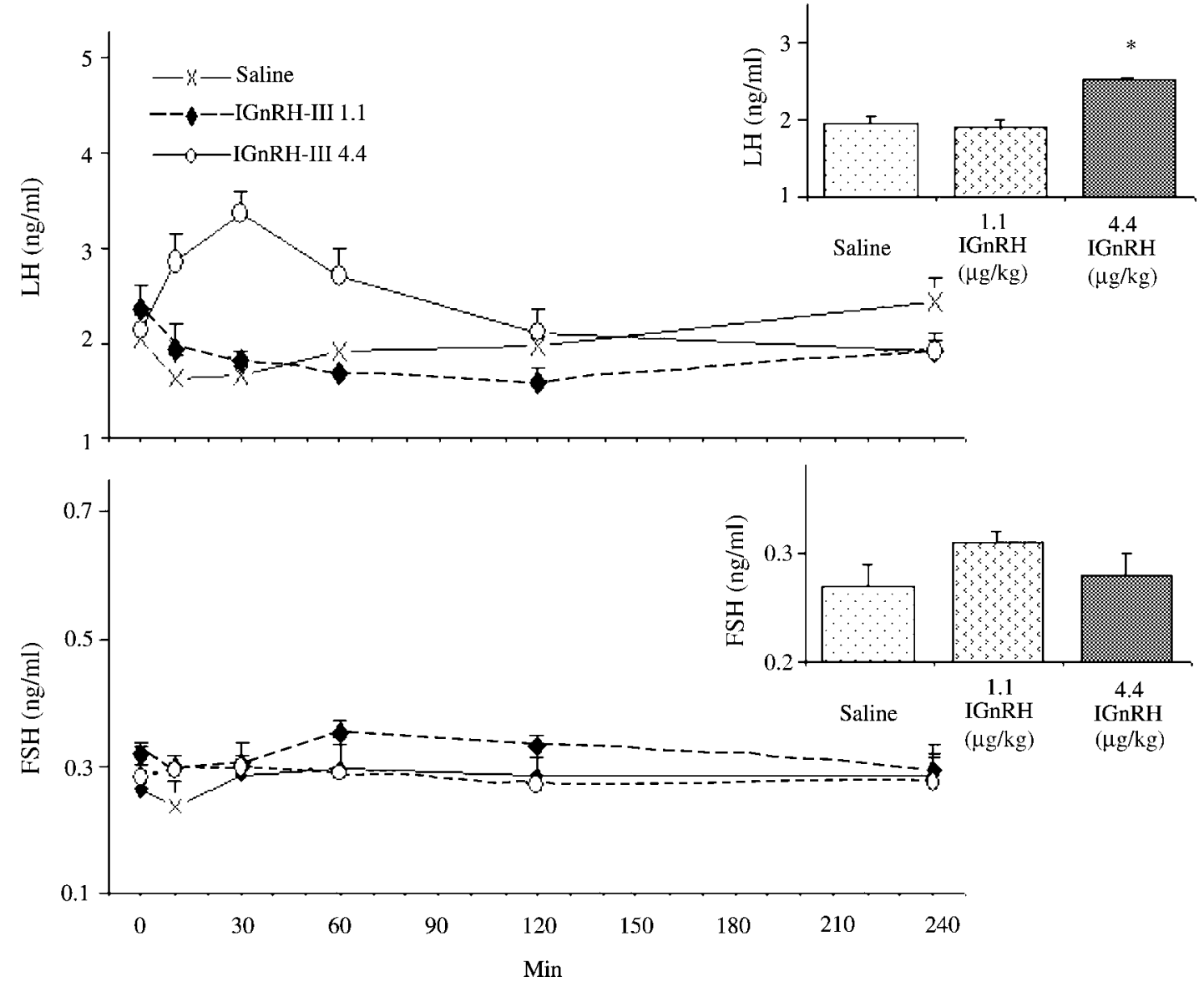

Figure 6 Temporal changes and overall mean concentrations ( \pm S.E.M.) of LH (top) and FSH (bottom) in intact cows during the mid-luteal phase of the estrous cycle (Experiment 4B). Cows were injected i.v. at time 0 with saline (control) or IGnRH-III. IGnRH-III at a dose of $4.4 \mu \mathrm{g} / \mathrm{kg}$ increased overall mean concentrations of LH but not FSH (insets). IGnRH-III at a dose of $1.1 \mu \mathrm{g} / \mathrm{kg}$ had no significant effect on release of either gonadotropin. ${ }^{*} P<0.001$ compared with saline ( $n=3$ cows per treatment).

NY, USA) for oFSH antisera and Dr Douglas Bolt (United States Department of Agriculture) for bFSH- $\beta$ antisera. We also acknowledge the advice of Dr Joanne Fortune and Dr Phillip Bridges, and the technical assistance of Tina Bryan, Marsha Green, Marlon Maciel, Melvin Davis, Randle Franke and Justin Kinnamon.

\section{References}

Bó GA, Baruselli PS, Moreno D, Cutaia L, Caccia M, Tríbulo $\mathrm{R}$ et al. 2002 The control of follicular wave development for self-appointed embryo transfer programs in cattle. Theriogenology 57 53-72.

Bolt DJ \& Rollins R 1983 Development and application of a radioimmunoassay for bovine follicle-stimulating hormone. Journal of Animal Science 56 146-154.

Clarke IJ, Cummins JT \& de Kretser DM 1983 Pituitary gland function after disconnection from direct hypothalamic influences in the sheep. Neuroendocrinology 36 376-384.

Dees WL, Dearth RK, Hooper RN, Brinsko SP, Romano JE, Rahe H et al. 2001 Lamprey gonadotropin-releasing hormone-III selectively releases follicle stimulating hormone in the bovine. Domestic Animal Endocrinology 20 279-288.

Dhariwal APS, Nallar R, Batt M \& McCann SM 1965 Separation of follicle-stimulating hormone-releasing factor from luteinizing hormone-releasing factor. Endocrinology 76 290-294.
Dubois EA, Zandbergen MA, Peute J \& Goos HJ 2002 Evolutionary development of three gonadotropin-releasing hormone $(\mathrm{GnRH})$ systems in vertebrates. Brain Research Bulletin 57 413-418.

Fajersson P, Stanko RL \& Williams GL 1999 Distribution and repeatability of anterior pituitary responses to $\mathrm{GnRH}$ and relationship of response classification to the postpartum anovulatory interval of beef cows. Journal of Animal Science 77 3043-3049.

Knobil E 1980 The neuroendocrine control of the menstrual cycle. Recent Progress in Hormone Research 36 53-88.

Kovacs M, Koppan M, Mezo I, Teplan I \& Flerko B 1993 Antiovulatory doses of antagonists of $\mathrm{LH}-\mathrm{RH}$ inhibit $\mathrm{LH}$ and progesterone but not FSH and estradiol release. Journal of Neuroendocrinology 5 603-608.

Kovacs M, Seprodi J, Koppan M, Horvath JE, Vincze B, Teplan I et al. 2002 Lamprey gonadotropin hormone-releasing hormone-III has no selective follicle-stimulating hormone-releasing effect in rats. Journal of Neuroendocrinology 14 647-655.

Krystek SR Jr, Dias JA, Reichert LE Jr \& Andersen TT 1985 Prediction of antigenic sites in follicle-stimulating hormones: difference profiles enhance antigenicity prediction methods. Endocrinology $1171125-1131$.

Lescheid DW, Terasawa E, Abler LA, Urbanski HF, Warby CM, Millar RP et al. 1997 A second form of gonadotropin-releasing hormone $(\mathrm{GnRH})$ with characteristics of chicken GnRH-II is present in the primate brain. Endocrinology 138 5618-5629. 
Lovas S, Palyi I, Vincze B, Horvath J, Kovacs M, Mezo I et al. 1998 Direct anticancer activity of gonadotropin-releasing hormone-III. Journal of Peptide Research 52 384-389.

Lumpkin MD \& McCann SM 1984 Effect of destruction of the dorsal anterior hypothalamus on follicle-stimulating hormone secretion in the rat. Endocrinology 115 2473-2480.

Marubayashi U, Yu WH \& McCann SM 1999 Median eminence lesions reveal separate hypothalamic control of pulsatile folliclestimulating hormone and luteinizing hormone release. Proceedings of the Society for Experimental Biology and Medicine 220 139-146.

McVey WR Jr \& Williams GL 1991 Mechanical masking of neurosensory pathways at the calf-teat interface: endocrine, reproductive, and lactational features of the suckled anestrous cow. Theriogenology 35 931-941.

Millar R, Lowe S, Conklin D, Pawson A, Maudsley S, Troskie B et al. 2001 A novel mammalian receptor for the evolutionarily conserved type II GnRH. PNAS 98 9636-9641.

Montaner AD, Mongiat L, Lux-Lantos VAR, Park MK, Fischer WH, Craig AG et al. 2001 Structure and biological activity of gonadotropin-releasing hormone isoforms isolated from rat and hamster brains. Neuroendocrinology $74202-212$.

Neill JD $2002 \mathrm{GnRH}$ and GnRH receptor genes in the human genome. Endocrinology 143 737-743.

Neill JD, Duck LW, Sellers JC \& Musgrove LC 2001 A gonadotropinreleasing hormone $(\mathrm{GnRH})$ receptor specific for $\mathrm{GnRH}$ II in primates. Biochemical and Biophysical Research Communications 282 1012-1018.

Padmanabhan V, Mieher CD, Borondy M, I'Anson H, Wood RI, Landefeld TD et al. 1992 Circulating bioactive follicle-stimulating hormone and less acidic follicle-stimulating hormone isoforms increase during experimental induction of puberty in the female lamb. Endocrinology 131 213-220.

Padmanabhan V, Karsch FJ \& Lee JS 2002 Hypothalamic, pituitary and gonadal regulation of FSH. Reproduction 59 (Suppl) 67-82.

Padmanabhan V, Brown MB, Dahl GE, Evans NP, Karsh FJ, Mauger DT, Neill JD \& Cleeff JV 2003 Neuroendocrine control of follicle-stimulating hormone (FSH) secretion: III. Is there a gonadotropin-releasing hormone-independent component of episodic FSH secretion in ovariectomized and luteal phase ewes? Endocrinology 144 1380-1392.

Pau KY, Gliessman PM, Oyama T \& Spies HG 1991 Disruption of $\mathrm{GnRH}$ pulses by anti-GnRH serum and phentolamine obliterates pulsatile LH but not FSH secretion in ovariectomized rabbits. Neuroendocrinology 53 382-391.
Rivier C, Rivier J \& Vale W 1986 Inhibin-mediated feedback control of follicle-stimulating hormone secretion in the female rat. Science 234 205-208.

Sower SA, Chiang Y, Lovas S \& Conlon JM 1993 Primary structure and biological activity of a third gonadotropin-releasing hormone from lamprey brain. Endocrinology 132 1125-1131.

Talavera F, Park CS \& Williams GL 1985 Relationships among dietary lipid intake, serum cholesterol, and ovarian function in Holstein heifers. Journal of Animal Science 60 1045-1051.

Tanner JW, Davis SK, McArthur NH, French JT \& Welsh TH Jr 1990 Modulation of growth hormone $(\mathrm{GH})$ secretion and $\mathrm{GH}$ mRNA levels by GH-releasing factor, somatostatin and secretagogues in cultured bovine adenohypophyseal cells. Journal of Endocrinology 125 109-115.

Wang QF, Farnworth PG, Findlay JK \& Burger HG 1988 Effect of purified $31 \mathrm{~K}$ bovine inhibin on the specific binding of gonadotropinreleasing hormone to rat anterior pituitary cells in culture. Endocrinology 123 2161-2166.

Watts CR, Mezei M, Murphy RF \& Lovas S 2001 Conformational space comparison of $\mathrm{GnRH}$ and IGnRH-III using molecular dynamics, cluster analysis and Monte Carlo thermodynamic integration. Journal of Biomolecular Structure and Dynamics $\mathbf{1 8}$ $733-748$.

Welsh TH Jr, Harms PG, McArthur NH \& Procknor M 1986 Regulation of adenohypophyseal hormones by hypothalamic neurohormones and activators of adenyl cyclase and protein kinase C. In Proceedings of 1st Membrane Protein Symposium, pp 703-713. Ed. S Goheen. San Diego, CA: Bio-Rad Laboratory Publishers.

Yu WH, Karanth S, Walczewska A, Sower SA \& McCann SM 1997 A hypothalamic follicle-stimulating hormone-releasing decapeptide in the rat. PNAS 94 9499-9503.

Yu WH, Karanth S, Sower SA, Parlow AF \& McCann SM 2000 The similarity of FSH-releasing factor to lamprey gonadotropin-releasing hormone III (I-GnRH-III). Proceedings of the Society for Experimental Biology and Medicine 224 87-92.

Yu WH, Karanth S, Mastronardi CA, Sealfon S, Dean C, Dees WL et al. 2002 Lamprey $\mathrm{GnRH}-\mathrm{III}$ acts on its putative receptor via nitric oxide to release follicle-stimulating hormone specifically. Experimental Biology and Medicine 227 786-793.

Received 16 June 2003

First decision 30 July 2003

Accepted 11 September 2003 